УДК 331.1

DOI: https://doi.org/10.26642/jen-2020-2(92)-7-14

Л.Л. Калініченко, Д.е.н., проф.

В.В. Смачило, к.е.н., доц. Д.В. Попович, здобувач

О.В. Авдісвська, здобувач

Харківський національний університет будівництва та архітектури

\title{
Процедура формування комунікативної політики підприсмства зі стейкхолдерами
}

Імплементація принципів сочіальної відповідальності у діяльність вітчизняних підприємств забезпечує інтеграцію украӥнських підприємств у світове глобальне бізнес-середовище, яке використовує стратегії корпоративної соціальної відповідальності як дієвий інструмент сталого розвитку. Важливим аспектом глобального бізнесу $\epsilon$ використання принципів прозорості та відкритості, щзо передбачають посилення ролі інформації, комунікації у діяльності організачій. Саме тому для вітчизняних підприємств нагальним є завдання розробки процедур формування комунікативної політики, яка б враховувала сучасні світові тенденції у иій сфері. Метою статті є розробка прочедури формування комунікативної політики підприємства на засадах визначення стейкхолдерів.

Авторами проаналізовано термінологію стосовно комунікативної політики підприємств та підходи до ї̈ формування. Було встановлено, щзо корпоративна сочіальна відповідальність на основі концепиї стейкхолдерів є невід 'ємною умовою успішності розвитку бізнес-структур на сучасному етапі. Ї̈ підтрунтям є ведення діалогу з усіма зацікавленими сторонами, щчо передбачає використання певних комунікачій та формування комунікативної політики. Виявлено певну неоднозначність сприйняття термінів «комунікаційна політика» та «комунікативна політика», які запропоновано тлумачити синонімічно та розуміти як иілеспрямовану діяльність підприємства зі встановлення та підтримання сприятливих взаємовідносин із стейкхолдерами на основі комунікацій для забезпечення взаємного сталого розвитку. Авторським колективом запропоновано процедуру формування комунікативної політики підприємства, яка базується на ідентифікації стейкхолдерів, встановленні збалансованості їхніх інтересів та визначені каналів комунікацій. Запропонована процедура є невід'ємною складовою КСВ-стратегї̈ підприємства.

Ключові слова: корпоративна сочіальна відповідальність; діалог; комунікачія; комунікативна політика; стейкхолдери; підприємство.

Актуальність теми. Імплементація принципів соціальної відповідальності у діяльність вітчизняних підприємств забезпечує інтеграцію українських підприємств у світове глобальне бізнес-середовище, яке використовує стратегії корпоративної соціальної відповідальності як дієвий інструмент сталого розвитку. Важливим аспектом глобального бізнесу $є$ використання принципів прозорості та відкритості, що передбачають посилення ролі інформації, комунікації в діяльності організацій. Саме тому для вітчизняних підприємств нагальним є завдання розробки процедур формування комунікативної політики, яка б враховувала сучасні світові тенденції у цій сфері.

Аналіз останніх досліджень та публікації, на які спираються автори. Аспектам ідентифікації стейкхолдерів та використання концепції стейкхолдерів присвячено публікації О.Кравченко, Я.Лагути, В.Смачило, Ю.Халіної [1-5]. Питання соціалізації економічних процесів бізнес-структур та корпоративної соціальної відповідальності розглянуто в роботах Л.Калініченко, М.Саприкіної та інших дослідників [6-9], а також у міжнародних стандартах [10-11]. У той же час, якщо питанням комунікаційної політики в маркетинговому аспекті присвячено велику кількість публікацій [12-14], то розкриття проблематики формування комунікативної політики на засадах соціальної відповідальності не має комплексного характеру та висвітлено в роботі [15].

Метою статті є розробка процедури формування комунікативної політики підприємства на засадах визначення стейкхолдерів.

Викладення основного матеріалу. Сучасний економічний розвиток невід’ємно пов'язаний із соціальною відповідальністю бізнес-структур, яка найчастіше розуміється як корпоративна соціальна відповідальність (КСВ). Безпосередньо концепцію КСВ було запропоновано в 1975 р. Кітом Девісом, який на основі дослідження діяльності багатьох корпорацій встановив, що соціальна відповідальність сприяє розвитку підприємств, а їі нівелювання веде до сповільнення темпів економічного зростання.

Одним із постулатів вказаної концепції стало розуміння ролі бізнесу як «двосторонньої відкритої системи», що передбачає не тільки врахування інтересів та впливів суспільства, а й відкритість до громадськості. Саме принцип транспарентності є базовим у формуванні демократичного, громадянського суспільства і передбачає встановлення діалогу та взаємну комунікацію між усіма учасниками. При цьому 
важлива роль відводиться так званій «стейкхолдерській теорії фірми», яка запропонована Е.Фріманом (1984р.) [2, 16]. Саме він вводить термін стейкхолдер (stakeholder) - зацікавлена особа - у сферу стратегічного управління фірмами та розглядає зовнішнє і внутрішнє середовища як сукупність осіб, інтереси яких необхідно враховувати у діяльності підприємства. У подальшому цей термін знаходить відображення у міжнародних стандартах, присвячених соціальній відповідальності. Так у стандарті ISO 26000 (2010р.) стейкхолдер - це особа або група осіб, зацікавлених у будь-яких рішеннях або діяльності організації [11]. В іншому стандарті - AA1000SES [10] - стейкхолдером вважається група, що може впливати на діяльність організації, або навпаки, здатна відчувати на собі вплив від діяльності організації, її продукції або послуг і пов’язаних з цим дій. Зауважується, що стейкхолдерами не є ті, хто просто може бути знайомий з організацією або мати думку про неї.

Найбільш вдалим, на наш погляд, є визначення корпоративної соціальної відповідальності, яке поєднує концепцію стейкхолдерів та сутність соціальної відповідальності бізнесу, що належить колективу дослідників КНЕУ [17]. Вони розкривають корпоративну соціальну відповідальність як «систему економічних, соціальних, екологічних заходів, а також етичних норм і цінностей компанії, які в сукупності забезпечують суспільну корисність їі діяльності, реалізуються на основі постійної взаємодії із зацікавленими сторонами (стейкхолдерами) і спрямовані на довгострокове поліпшення іміджу та ділової репутації компанії, а також на набуття конкурентних переваг і стратегічної стійкості бізнес-структури».

Таким чином, аби бізнес-структура була успішною, їй необхідно знати своїх стейкхолдерів та комунікувати з ними, щоб знати їх інтереси й потреби, що передбачає використання сукупності певних комунікацій та формування комунікативної політики організації.

Вивчення існуючих досліджень щодо формування комунікативної політики у вітчизняному науковому полі дозволило встановити практику використання двох термінів: «комунікативна політика» та «комунікаційна політика». Їх варіації ототожнюються - дослідники не вбачають жодної різниці, окрім стилістичного викладення [18]. У цьому дослідженні автор використовує терміни комунікативна та комунікаційна політики не розділяючи їх, а як похідні від терміна «комунікація». Як синоніми зазначено використання вказаних категорій і в джерелі [19]: «комунікативна політика (комунікаційна політика) звід правил, позиція, а також опис можливої реакції на події в комунікативному просторі, в якому існує об’єкт комунікації».

3 цього визначення бачимо, що в основі такої політики покладено комунікацію. Також на pecypci [20], у темі «Комунікативна політика організації», окрім терміна комунікативна, як зазначено в темі, зустрічається термін комунікаційна, що спонукає до їх синонімічного сприйняття.

Комунікативна політика, відповідно до [20], розуміється як «цілеспрямована діяльність підприємства зі встановлення та підтримання сприятливих ділових відносин з іншими підприємствами, громадськими та професійними об'єднаннями, групами громадян (зовнішня політика) та власним персоналом (внутрішня політика)». 3 цього визначення чітко не відстежується використання категорії «комунікація» як базису формування комунікативної політики, але передбачається певна діяльність щодо встановлення відносин. Вважаємо, що останнє неможливе без використання комунікації та $є$ саме собою певним видом комунікації. Саме тому необхідним є вивчення сутності категорії «комунікація» для зіставлення словосполучення «встановлення відносин» і терміну «комунікація».

У концепції проєкту Закону України «Про основні засади державної комунікативної політики», яка схвалена розпорядженням Кабінету Міністрів України від 13 січня 2010 р. № 85-р [21], передбачено визначення термінів «державна комунікативна політика», «комунікація». Але на цей момент закон не прийнято і встановленого визначення не існує. У [22] надано визначення комунікативної діяльності: «Комунікативна діяльність - це динамічна система, в якій зв'язки (особливо в побудові взаємин із громадськістю) можуть установлюватися однозначно і мати прогностичну спрямованість. Така діяльність є багатоканальною системою взаємодії, має комплекс професійних завдань, які стосуються комунікації, міжособистісного спілкування, міжгрупового спілкування, процесів спілкування між особистістю і групою, а також факторів впливу на навколишніх, з метою спонукання їх до діяльності».

Вказану діяльність розподілена на внутрішню та зовнішню. Окрім того, зазначено [22], що стосовно зарубіжних сучасних підходів до комунікацій і комунікативної діяльності, комунікація розглядається 3 позицій діяльності або діяльнісного підходу, що дало можливість багатьом державам сформулювати складові частини комунікаційних політик, стратегій, планів тощо. Також зазначено, що правомірним є використання двох понять: «комунікативна політика» і «комунікаційна політика». При цьому остання категорія більш широка, оскільки визначає особливості взаємодії з населенням шляхом використання IT-технологій.

Зважаючи на тотальну діджиталізацію всіх процесів як на рівні держави, так і на рівні підприємства, єдина різниця, яка полягає у використанні IT-технологій, між комунікативною та комунікаційною політиками є несуттєвою. Тому вважаємо, що доцільно використовувати вказані поняття як синоніми зі стилістичною перевагою в сторону «комунікативної» як такої, визначення якої передбачено майбутнім законодавчим актом. На користь ототожнення та синонімічного використання вказаних категорій говорить і те, що в їх основу покладено комунікацію. 
У дослідженні [22] вказується, що на державному рівні багато країн виокремлює комунікативну політику, яка має: принципи, цілі, рішення, правила, заходи, кодекси поведінки. Водночас кожна держава сама обирає формат документа, який є основою для реалізації на практиці комунікативної політики. Як приклад, наводяться: Політика комунікацій; Комунікаційна стратегія; Стратегія комунікацій та План дій; Координація комунікативної політики; Політика урядової зовнішньої комунікації; Комунікаційна стратегія громадськості [22].

Термін «комунікація» походить 3 латини від іменника «соmmunicatio», що означає «єдність, передача, з'єднання, повідомлення»; від дієслова «сотmunico», тобто «роблю спільним, повідомляю, з'єдную», є похідним від латинського «соmmunis»- спільний i розуміється як «процес обміну інформацією (фактами, ідеями, поглядами, емоціями тощо)».

Це поняття також знайшло відображення в наукових дослідженнях та навчальній літературі (рис. 1).

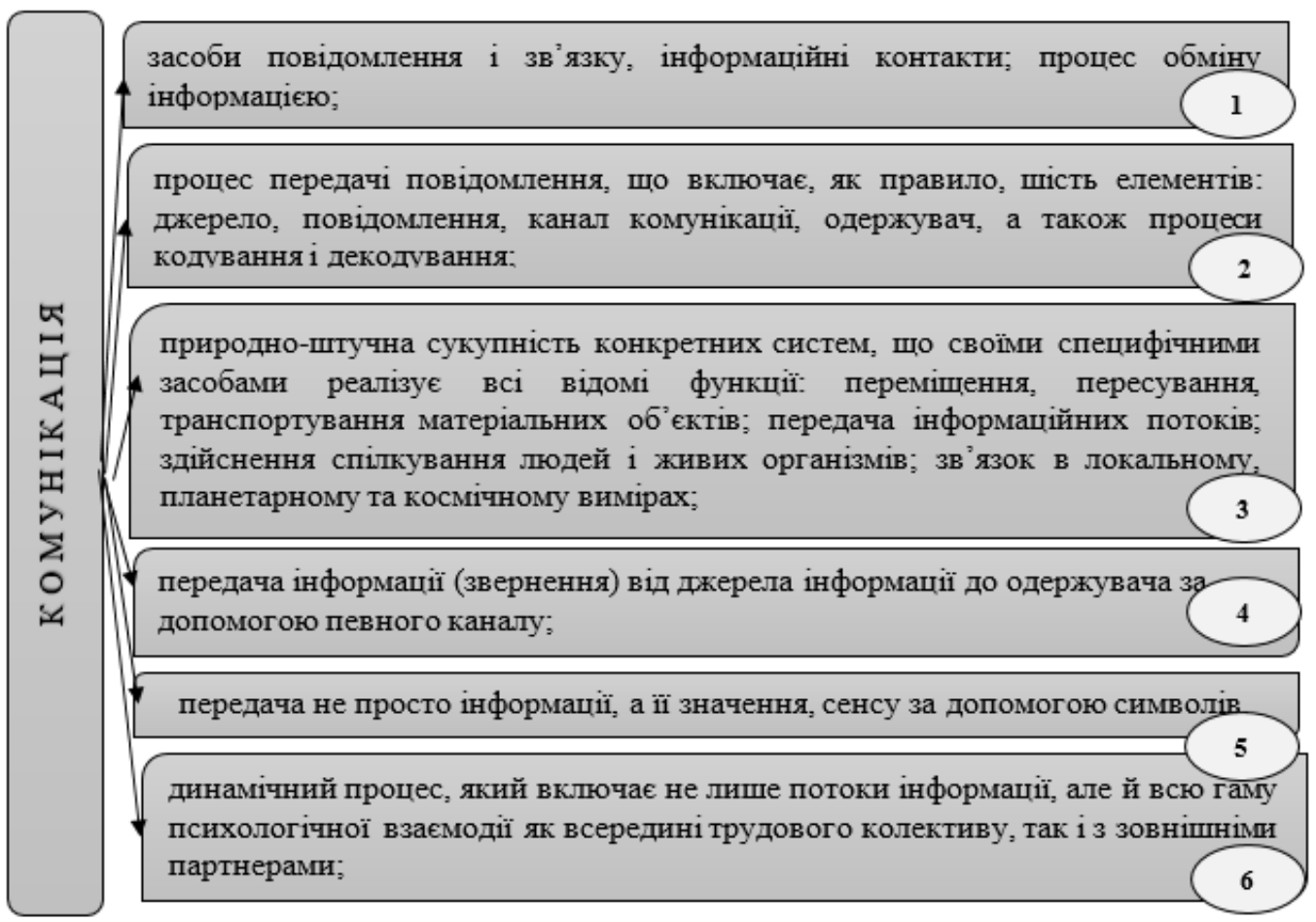

Джерело: побудовано на основі [12]

\section{Рис. 1. Узагальнення тлумачень категорії «комунікація»}

Базуючись на сукупності визначень, що наведено на рисунку 1, можна зробити висновки:

- категорія комунікація розуміється як іменник та як дієслово, тобто як певний засіб і дія;

- існує широке (визначення 3) та вузьке (визначення 1) розуміння комунікації;

- комунікації передбачають не просто процес, а динамічний процес;

- комунікації передбачають передачу не просто інформації, але і її сенсу;

- процес передачі інформації $\epsilon$ структурований: «джерело-одержувач» або «джерело, повідомлення, канал комунікації, одержувач, а також процеси кодування і декодування»;

- стосовно підприємства (визначення 6) передача відбувається не лише всередині підприємства, але й ззовні.

Окрім того, вважаємо, що: 1) комунікація передбачає певну мету, тому можна говорити про цілеспрямований процес передачі інформації; 2) відбувається модифікація символів передачі інформації залежно від цільової групи, на яку спрямована інформація.

Таким чином, тлумачення комунікації як процесу, на думку авторів, передбачає його розуміння як цілеспрямованого динамічного процесу обміну інформацією між джерелом та одержувачем за допомогою заздалегідь визначених символів, що $є$ модифікованими залежно від цільової групи.

Тип відносин може бути [23]: суб'єктно-об'єктний, монологічний, з одностороннім зв'язком або комунікативний - суб'єктно-суб'єктний, діалогічний, зі зворотним зв'язком [23]. Однозначно сучасний тип комунікативної політики передбачає діалог з усіма учасниками комунікації та відповідає сутності корпоративної соціальної відповідальності. 
Визначившись із поняттям комунікації, перейдемо до аналізу категорії «комунікаційна політика підприємства», базуючись на тлумаченнях, що існують у вітчизняному науковому просторі та узагальнено в таблиці 1. Зауважимо, що у вітчизняному науковому просторі майже відсутні визначення комунікативної політики підприємства.

Таблиия 1

Узагальнення визначень «комунікаиійна політика підприємства»

\begin{tabular}{|c|c|}
\hline Комунікаційна політика підприємства - & Джерело \\
\hline $\begin{array}{l}\text { процес формування спрямованих на ринок і від ринку (при ринкових дослідженнях) } \\
\text { потоків інформації. До основних елементів комунікаційної політики належать: реклама; } \\
\text { стимулювання збуту; робота з громадськістю (паблік рилейшнз); формування фірмового } \\
\text { стилю; формування торгової марки; упакування }\end{array}$ & {$[24]$} \\
\hline $\begin{array}{l}\text { комплекс заходів, спрямованих на ефективне та систематичне здійснення маркетингових } \\
\text { комунікацій для забезпечення досягнення маркетингових цілей підприємства }\end{array}$ & {$[14]$} \\
\hline $\begin{array}{l}\text { перспективний курс дій підприємства та наявність у нього обгрунтованої стратегії } \\
\text { використання комплексу комунікаційних засобів взаємодії } 3 \text { усіма суб'єктами } \\
\text { маркетингової системи, яка забезпечує стабільну й ефективну діяльність із формування } \\
\text { попиту і просування товарів і послуг на ринок }\end{array}$ & {$[25]$} \\
\hline $\begin{array}{l}\text { система просування товару на ринок, одна зі складових комплексу маркетингу, що містить: } \\
\text { паблік рилейшнз, рекламу, стимулювання збуту, персональні продажі, виставки та } \\
\text { ярмарки, торгові переговори }\end{array}$ & {$[26]$} \\
\hline $\begin{array}{l}\text { комплекс заходів, які використовує підприємство для інформування, переконання, } \\
\text { нагадування і формування поглядів споживача на товар (послугу) та імідж підприємства }\end{array}$ & {$[27]$} \\
\hline $\begin{array}{l}\text { розроблення комплексу стимулювання заходів щодо забезпечення ефективної взаємодії } \\
\text { бізнес-партнерів, організації реклами, методів стимулювання збуту, зв’язків із } \\
\text { громадськістю та персонального продажу }\end{array}$ & {$[28]$} \\
\hline $\begin{array}{l}\text { цілеспрямований, економічно обгрунтований процес передачі інформації про продукт і } \\
\text { його цінність до споживача через різні канали } 3 \text { метою формування у нього бажання } \\
\text { придбати саме визначений продукт }\end{array}$ & [29] \\
\hline $\begin{array}{l}\text { комплекс заходів щодо забезпечення ефективної взаємодії бізнес-партнерів, організації } \\
\text { реклами, методів стимулювання збуту і зв’язку з громадськістю }\end{array}$ & {$[30]$} \\
\hline $\begin{array}{l}\text { поєднання засобів реклами, персональних продажів, стимулювання збуту та формування } \\
\text { громадської думки }\end{array}$ & [13] \\
\hline
\end{tabular}

3 аналізу наведених у таблиці 1 визначень, базуючись на морфологічному аналізі, можемо зробити такі висновки:

- комунікаційна політика підприємства означає: комплекс заходів [14, 27, 28, 30], систему заходів [26], процес формування [24, 29], курс дій [25]. Ключові слова визначень мають дієвий характер, що орієнтує розуміння сутності цієї категорії на певну дію;

- щодо орієнтації такого процесу, то його спрямованість найчастіше стосується саме маркетингових аспектів діяльності. Водночас, згідно з деякими визначеннями, цей процес стосується зв'язків із громадськістю [28], формування громадської думки, іміджу підприємства [27, 13], взаємодії 3 бізнес-партнерами [28], суб'єктів маркетингової системи [25].

Спираючись на викладене вище, розуміння комунікативної політики підприємства буде ширшим, аніж просто процес обміну інформацією та їі передачі в маркетинговому аспекті. У подальшому будемо

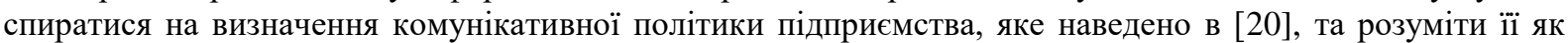
цілеспрямовану діяльність підприємства зі встановлення та підтримання сприятливих взаємовідносин із стейкхолдерами на основі комунікацій для забезпечення взаємного сталого розвитку.

Визначившись із сутнісним навантаженням комунікативної політики, іiї можливими складовими, а також на основі концепції стейкхолдерів, пропонується процедура формування комунікативної політики підприємства. На відміну від існуючих, вона у повному обсязі враховуватиме всі аспекти діяльності підприємства (а не лише маркетинговий), базуватиметься на комунікаціях між різними стейкхолдерами (врахування стейкхолдерської концепції) та буде інтегрована в загальну КСВ-стратегію підприємства (рис. 2).

Відповідно до рисунка 2 бачимо, що на підприємстві має бути створена та функціонувати робоча група 3 формування КСВ-стратегії, яка здійснює іiі розробку, визначає місію та цілі як іiі складові. Оскільки комунікативна політика є складовою загальної КСВ-стратегії підприємства, то вона має бути узгоджена зі стратегією, а цілі комунікативної політики враховувати та доповнювати цілі КСВ-стратегії. Аналогічно в межах робочої групи з розробки стратегії створюється робоча група для розробки певної політики (в цьому випадку - комунікативної). 
Формування комунікативної політики, насамперед, передбачає визначення іiі цілей та аналіз поточного стану комунікацій на підприємстві, що є взаємопов'язаним процесом. Після чого доцільно здійснювати визначення стейкхолдерів підприємства. Цей етап структуровано на шість складових, де завершальним є визначення рівня збалансування інтересів стейкхолдерів.

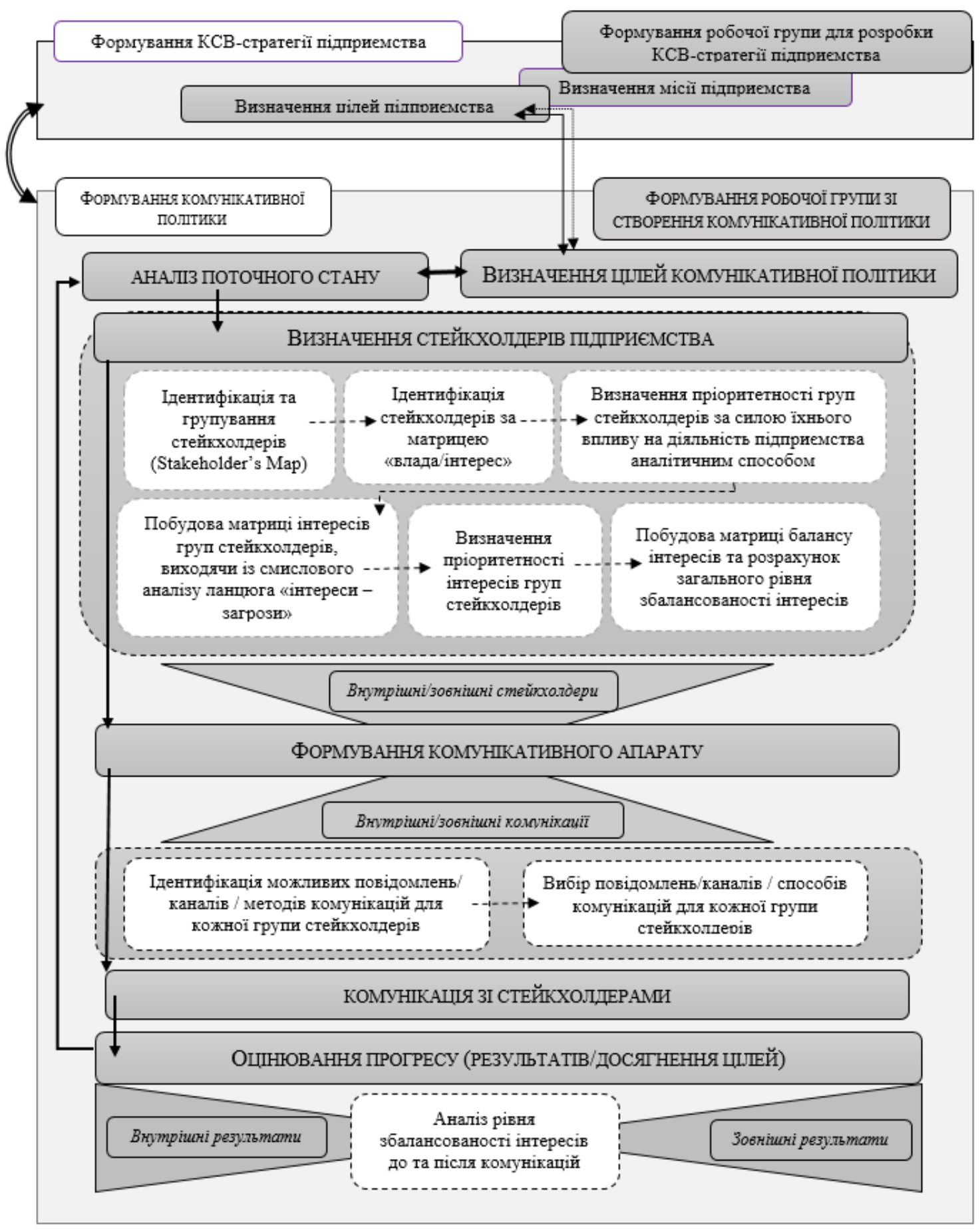

Джерело: розроблено авторами

\section{Рис. 2. Процедура формування комунікативної політики підприємства}

На цьому етапі доцільно застосувати такий інструмент, як «карта стейкхолдерів», що дозволить візуалізувати групи зацікавлених сторін. На другому етапі ідентифікованих стейкхолдерів доцільно розділити за силою впливу - прямий, непрямий тощо, та рівнем інтересу - високий, низький тощо. Більш докладно такий етап описувався авторами в роботі [5]. 
Всі стейкхолдери, які буде визначено, групуються в зовнішніх та внутрішніх, адже це впливатиме на комунікативний апарат та очікувані результати.

Під час формування комунікативного апарату, відповідно до визначених стейкхолдерів, формуються повідомлення, час (графік) їх здійснення, визначаються канали та методи комунікації, що дозволяє врахувати інтереси та специфіку кожного стейкхолдера.

Наступний етап - безпосередньо сама комунікація зі стейкхолдерами, після якої доцільно оцінити результат такої комунікації. На цьому етапі можна визначити, чи досягнуто встановлені цілі, очікувані результати у розрізі стейкхолдерів та зміну рівня збалансованості інтересів стейкхолдерів.

Проведений аналіз дасть змогу здійснити контрольні заходи та скоригувати цілі комунікативної політики і, відповідно, цілі КСВ-стратегії та саму КСВ-стратегію.

Отже, було вивчено теоретико-методичні засади формування комунікативної політики підприємств із врахуванням стейкхолдерської концепції, що дозволило запропонувати процедуру її формування.

Висновки та перспективи подальших досліджень. Встановлено, що корпоративна соціальна відповідальність на основі концепції стейкхолдерів є невід'ємною умовою успішності розвитку бізнесструктур на сучасному етапі. Ї̈̈ підгрунтям $є$ ведення діалогу з усіма зацікавленими сторонами, що передбачає використання певних комунікацій та формування комунікативної політики. Виявлено певну неоднозначність сприйняття термінів «комунікаційна політика» та «комунікативна політика», які запропоновано тлумачити синонімічно та розуміти як цілеспрямовану діяльність підприємства зі встановлення та підтримання сприятливих взаємовідносин із стейкхолдерами на основі комунікацій для забезпечення взаємного сталого розвитку. Запропоновано процедуру формування комунікативної політики підприємства, яка базується на ідентифікації стейкхолдерів та комунікативного апарату відповідно до визначених груп внутрішніх та зовнішніх зацікавлених сторін. Запропонована процедура $\epsilon$ невід’ємною складовою КСВ-стратегії підприємства.

\section{Список використаної літератури:}

1. Кравченко O. Стейкхолдери як агенти зовнішніх та внутрішніх комунікацій в організаціях сфери масового спорту та спорту для всіх / О.Кравченко // Молода спортивна наука України. - 2014. - Т. 4. - С. 47-52.

2. Лагута Я.М. Стейкхолдерський підхід в корпоративній соціальній відповідальності компанії / Я.М. Лагута // Науковий вісник Міжнародного гуманітарного університету. - 2017. - №1 - - С. 130-133.

3. Смачило В.В. Формування соціальної звітності будівельних підприємств / В.В. Смачило, В.Ю. Халіна, I.A. Скрипка // Економіка, управління та адміністрування. - 2019. - № 4. - С. 189-194.

4. Смачило В.В. Соціальна відповідальність бізнесу крізь призму комунікацій зі стейкхолдерами / В.В. Смачило, В.Ю. Халіна, Т.С. Васильєва // Ефективна економіка. - 2018. - № 9 [Електронний ресурс]. Режим доступу : http://www.economy.nayka.com.ua/?op=1\&z=6538.

5. Смачило В.В. Процедура аналізу стейкхолдерів підприємства / B.В. Смачило, О.М. Колмакова, Ю.В. Коломієць // Економіка та суспільство. - 2017. - № 12 [Електронний ресурс]. - Режим доступу : http://economyandsociety.in.ua/journal-12/19-stati-12/1334-smachilo-v-v-kolmakova-o-m-kolomiets-yu-v.

6. Калініченко Л.Л. Світовий досвід ведення соціально орієнтованого бізнесу / Л.Л. Калініченко, A.С. Устіловська // Науково-виробничий журнал «Бізнес-навігатор». - 2017. - Вип. 4-2 (43). - С. 71-75

7. Прозорість і корпоративна соціальна відповідальність / I.Курінна., В.Малярчук, М.Саприкіна та ін. - К. : Юстон, 2015. - 47 с.

8. Корпоративна соціальна відповідальність: моделі та управлінська практика : підручник / M.Саприкіна, О.Ляшенко, М.Саєнсус та ін. ; за наук. ред. О.Редькіна. - К. : ТОВ «Фарбований лист», 2011. - 480 с.

9. Абросимова Е.Б. Системный анализ стейкхолдеров / Е.Б. Абросимова, И.М. Седельникова [Електронний pecypc]. - Режим доступу : http://www.hse.ru/data/2013/03/05/1292978681.

10. Стандарт AA1000SES 2015 [Електронний ресурс]. - Режим доступу : https://www.accountability.org/wpcontent/uploads/2016/10/AA1000SES_2015.pdf.

11. Керівництво з соціальної відповідальності ISO/DIS 26000 / Міжнародна організація стандартизації [Електронний ресурс]. - Режим доступу : isotc.iso.org.

12. Харчук Д.Л. Комунікаційна політика як складова комплексу маркетингу підприємства / Д.Л. Харчук, I.O. Клімова [Електронний ресурс]. - Режим доступу : http://eprints.zu.edu.ua/24990/1/Kharchuk.PDF.

13. Павленко I.Г. Комунікаційна політика як елемент системи маркетингу підприємства у процесах сучасного комунікаційного суспільства / І.Г. Павленко // Академічний огляд. - 2013. - № 1 (38). - С. 109-113.

14. Слюсарєва Л.А. Удосконалення комунікаційної політики підприємства / Л.А. Слюсарєва, О.М. Костіна [Електронний ресурс]. - Режим доступу : http://economyandsociety.in.ua/journal/16_ukr/74.pdf.

15. Мирошниченко Ю.О. Вплив КСВ-комунікації на максимізацію вартості підприємства / Ю.О. Мирошниченко, Д.С. Лантушенко, К.В. Зеленська // Східна Європа: економіка, бізнес та управління 2019. - Вип. 6 (23). - С. 329-334.

16. Freeman E. Strategic Management: A stakeholder approach / E.Freeman // Boston : Pitman, 1984. - 266 p. [Electronic resource]. - Access mode : http://bookre.org/reader?file=1164948\&pg=6.

17. Соціальна відповідальність : навч. посіб. / А.М. Колот, О.А. Грішнова, О.О. Герасименко та ін. ; за заг. ред. д.е.н., проф. А.М. Колота. - К. : КНЕУ, 2015. - 519 с. 
18. Войнаренко С.М. Комунікативна політика підприємств в сучасних умовах / C.M. Войнаренко // Вісник Хмельницького національного університету. - 2011. - № 6, Т. 2. - С. 51-54.

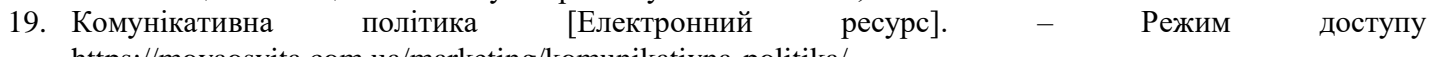
https://moyaosvita.com.ua/marketing/komunikativna-politika/.

20. Комунікативна політика організації [Електронний ресурс]. - Режим доступу : https://studfile.net/preview/5043857/page:15/.

21. Концепція проєкту Закону України «Про основні засади державної комунікативної політики» [Електронний peсурс]. - Режим доступу : https://www.kmu.gov.ua/npas/243246389.

22. Драгомирецька Н.M. Комунікативна діяльність в державному управлінні : навч. посіб. / Н.М. Драгомирецька, К.С. Кандагура, А.В. Букач. - Одеса : ОРІДУ НАДУ, 2017 - 180 с.

23. Дніпренко Н. Запровадження комунікативної політики - об'єктивний виклик часу / Н.Дніпренко [Електронний pecypc]. - Режим доступу : http://visnyk.academy.gov.ua/wp-content/uploads/2013/11/2009-4-11.pdf.

24. Каніщенко О.Л. Міжнародний маркетинг: Теорія і господарські ситуації : навч. посіб. / О.Л. Каніщенко. 2-ге вид., перероб. - К. : ІВЦ «Політехніка», 2004. - 152 с.

25. Афанасьев Н.В. Экономика предприятия / Н.В. Афанасьев, А.Б. Гончаров // Х. : ИД «ИНЖЭК», 2004. -528 с.

26. Балабанова Л.В. Маркетинг підприємства : навч. посіб. / Л.В. Балабанова, В.В. Холод, І.В. Балабанова. - К. : Центр учбової літератури, 2012. - 612 с.

27. Буряк П.Ю. Маркетинг : навч. посіб. / П.Ю. Буряк, Б.А. Карпінський, Я.Ю. Карпова. - Львів : Професіонал, 2008. $-318 \mathrm{c}$.

28. Іващенко B.I. Економічний аналіз господарської діяльності : навч. посіб. / В.І. Іващенко, М.А. Болюх. - К. : ЗАТ «Нічлава», 1999. - 204 с.

29. Магалецький А.B. Комунікаційна політика як ефективний інструмент підвищення конкурентоспроможності підприємств готельного господарства / A.B. Магалецький [Електронний ресурс]. - Режим доступу : http://www.economy.nayka.com.ua/index.php? operation=1\&iid=391.

30. Окландер М.A. Маркетингові комунікації промислових підприємств в умовах інформаційної економіки / М.А. Окландер, І.Л. Литовченко, М.І. Ботушан. - К. : Знання, 2011. - 265 с.

\section{References:}

1. Kravchenko, O. (2014), «Stejkholdery jak agenty zovnishnih ta vnutrishnih komunikacij v organizacijah sfery masovogo sportu ta sportu dlja vsih», Moloda sportyvna nauka Ukrai'ny, Vol. 4. pp. 47-52.

2. Laguta, Ja.M. (2017), «Stejkholders'kyj pidhid v korporatyvnij social'nij vidpovidal'nosti kompanii», Naukovyj visnyk Mizhnarodnogo gumanitarnogo universytetu, No. 1. pp. 130-133.

3. Smachylo, V.V., Halina, V.Ju. and Skrypka, I.A. (2019), «Formuvannja social'noi' zvitnosti budivel'nyh pidpryjemstv», Ekonomika, upravlinnja ta administruvannja, No. 4. pp. 189-194.

4. Smachylo, V.V., Halina, V.Ju. and Vasyl'jeva, T.S. (2018), «Social'na vidpovidal'nist' biznesu kriz' pryzmu komunikacij zi stejkholderamy», Efektyvna ekonomika, No. 9, [Online], available at: http://www.economy.nayka.com.ua/?op=1\&z=6538

5. Smachylo, V.V., Kolmakova, O.M. and Kolomiiets, Yu.V. (2017), «Protsedura analizu steikkholderiv pidpryiemstva», Ekonomika ta suspilstvo, No. 12, [Online], available at: http://economyandsociety.in.ua/journal12/19-stati-12/1334-smachilo-v-v-kolmakova-o-m-kolomiets-yu-v

6. Kalinichenko, L.L. and Ustilovs'ka, A.S. (2017) «Svitovyj dosvid vedennja social'no orijentovanogo biznesu», Naukovo-vyrobnychyj zhurnal «Biznes-navigator», No. 4-2 (43), pp. 71-75.

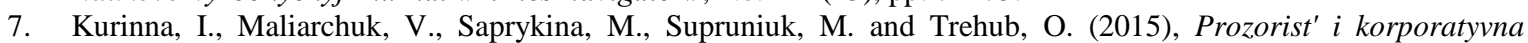
social'na vidpovidal'nist', Polihrafiia «Juston», K., 47 p.

8. Saprykina, M., Ljashenko, O., Sajensus, M. and Mis'ko, G. et al. (2011), Korporatyvna social'na vidpovidal'nist': modeli ta upravlins'ka praktyka, in Red'kin, O. (ed.), TOV «Farbovanyj lyst», K., 480 p.

9. Abrosimova, E.B. and Sedel'nikova, Y.M. (2013), Sistemnyi analiz steikkholderov, [Online], available at: http://www.hse.ru/data/2013/03/05/1292978681

10. Standart AA1000SES 2015, [Online], available at: https://www.accountability.org/wpcontent/uploads/2016/10/AA1000SES_2015.pdf

11. Mizhnarodna organizacija standartyzacii', Kerivnyctvo z social'noi' vidpovidal'nosti ISO/DIS 26000, [Online], available at: isotc.iso.org

12. Harchuk, D.L. and Klimova, I.O., Komunikacijna polityka jak skladova kompleksu marketyngu pidpryjemstva, [Online], available at: http://eprints.zu.edu.ua/24990/1/Kharchuk.PDF

13. Pavlenko, I.G. (2013), «Komunikacijna polityka jak element systemy marketyngu pidpryjemstva u procesah suchasnogo komunikacijnogo suspil'stva», Akademichnyj ogljad, No. 1 (38), pp. 109-113.

14. Sljusarjeva, L.A. and Kostina, O.M. (2016), Udoskonalennja komunikacijnoi' polityky pidpryjemstva, [Online], available at: http://economyandsociety.in.ua/journal/16_ukr/74.pdf

15. Myroshnychenko, Ju.O., Lantushenko, D.S. and Zelens'ka, K.V. (2019), «Vplyv KSV-komunikacii' na maksymizaciju vartosti pidpryjemstva», Shidna Jevropa: ekonomika, biznes ta upravlinnja, Issue 6 (23), pp. 329-334, [Online], available at: DOI: https://doi.org/10.32782/easterneurope.23-49

16. Freeman, E. (1984), Strategic Management: A stakeholder approach, Pitman, Boston, 266 p., [Online], available at: http://bookre.org/reader?file $=1164948 \& p g=6$

17. Kolot, A.M., Grishnova, O.A. and Gerasymenko, O.O. et al. (2015), Social'na vidpovidal'nist', navch. posib., in D.Sc. Kolota, A.M. (ed.), KNEU, K., 519 p. 
18. Vojnarenko, S.M. (2011), «Komunikatyvna polityka pidpryjemstv v suchasnyh umovah», Visnyk Hmel'nyc'kogo nacional'nogo universytetu, No. 6, Vol. 2, pp. 51-54.

19. Komunikatyvna polityka, [Online], available at: https://moyaosvita.com.ua/marketing/komunikativna-politika/

20. Komunikatyvna polityka organizacii', [Online], available at: https://studfile.net/preview/5043857/page:15/

21. Koncepcija projektu Zakonu Ukrai'ny «Pro osnovni zasady derzhavnoi' komunikatyvnoi' polityky», [Online], available at: https://www.kmu.gov.ua/npas/243246389

22. Dragomyrec'ka, N.M., Kandagura, K.S. and Bukach, A.V. (2017), Komunikatyvna dijal'nist' v derzhavnomu upravlinni, ORIDU NADU, Odesa, $180 \mathrm{p}$

23. Dniprenko, N. (2013), «Zaprovadzhennja komunikatyvnoi' polityky - ob'jektyvnyj vyklyk chasu», [Online], available at: http://visnyk.academy.gov.ua/wp-content/uploads/2013/11/2009-4-11.pdf

24. Kanishhenko, O.L. (2004), Mizhnarodnyj marketyng: Teorija i gospodars'ki sytuacii', IVC «Politehnika», K., 152 p.

25. Afanas'ev, N.V. and Goncharov, A.B. (2004), Ekonomika predpriyatiya, YD «YNZhEK», H., 528 p.

26. Balabanova, L.V., Holod, V.V.and Balabanova, I.V. (2012), Marketyng pidpryjemstva, Centr uchbovoi' literatury, K., $612 \mathrm{p}$.

27. Burjak, P.Ju., Karpins'kyj, B.A. and Karpova, Ja.Ju. (2008), Marketyng, Profesional, L'viv, 318 p.

28. Ivashhenko, V.I. and Boljuh, M.A. (1999), Ekonomichnyj analiz gospodars'koi' dijal'nosti, ZAT «Nichlava», K., $204 \mathrm{p}$.

29. Magalec'kyj, A.V. (2010), «Komunikacijna polityka jak efektyvnyj instrument pidvyshhennja konkurentospromozhnosti pidpryjemstv gotel'nogo gospodarstva», [Online], available at: http://www.economy.nayka.com.ua/?op=1\&z=391

30. Oklander, M.A., Lytovchenko, I.L. and Botushan, M.I. (2011), Marketyngovi komunikacii' promyslovyh pidpryjemstv $v$ umovah informacijnoi' ekonomiky, Znannja, K., 265 p.

Калініченко Людмила Леонідівна - доктор економічних наук, професор, завідувач кафедри економіки Харківського національного університету будівництва та архітектури.

Наукові інтереси:

- у управління персоналом;

- адаптивний розвиток та соціалізація бізнесу;

- підприємництво.

http://orcid.org/0000-0001-9847-8448.

E-mail: dk111905@gmail.com.

Смачило Валентина Володимирівна - кандидат економічних наук, доцент, професор кафедри економіки Харківського національного університету будівництва та архітектури.

Наукові інтереси:

- у управління персоналом;

- економіка праці та підприємства;

- соціальна відповідальність та підприємництво.

http://orcid.org/0000-0002-6153-1564.

E-mail: miroslava.valya@ukr.net.

Попович Дарина Володимирівна - здобувач ступеня магістр спеціальності 051 «Економіка» Харківського національного університету будівництва та архітектури.

Наукові інтереси:

- соціальна відповідальність та комунікації.

Авдісвська Ольга Володимирівна - здобувач ступеня магістр спеціальності 051 «Економіка» Харківського національного університету будівництва та архітектури.

Наукові інтереси:

- корпоративна соціальна відповідальність;

- управління персоналом. 